\title{
Establishment of the shoot and callus culture of an important medicinal plant Plumbago zeylanica
}

\begin{abstract}
Plumbago zeylanica is an important medicinal plant which belongs to the Plumbaginaceae family. It possesses antibacterial, hepato protective, and central nervous system stimulatory activity, anti-fungal, anti-inflammatory, antihyperglycemic, anti-cancer and anti-atherosclerotic activity. The objective of this study was to assess the effect two cytokinins (BAP and Kinetin) on shoot growth and two auxin on callus induction (2, 4-D and NAA). Highest multiple shoots $(4.33 \pm 0.63)$ and length of shoot $(5.01 \pm 0.53)$ were induced from nodal explants on modified MS medium supplemented with the $1.0 \mathrm{mg} / \mathrm{L}$ 6-benzyadenine and $3 \%$. Among the two auxin used for the investigation leave explants showed highest callus induction in MS media supplement with $1.0 \mathrm{mg} / 12,4-\mathrm{D}$.
\end{abstract}

Volume 7 Issue 5 - 2017

\author{
Arpita Roy, Navneeta Bharadvaja \\ Department of Biotechnology, Delhi Technological University, \\ India
}

Correspondence: Navneeta Bharadvaja, Plant Biotechnology Laboratory, Department of Biotechnology, Delhi Technological University, New Delhi-42, India, Email navneetab@dtu.ac.in

Received: September II, 2017| Published: October 26, 2017

\section{Introduction}

Medicinal plants are one of the important sources of natural products, which include essential oils, fragrances, pigments, feedstock, and pharmaceuticals. They are of great interest to the researches in biotechnology field as most of the pharmaceutical industries depend on them Chand et al. ${ }^{1}$ Plumbago zeylanica is an important medicinal plant which belongs to the Plumbaginaceae family. It is commonly known as Chitrak and Lead word. The plants consists of various bioactive compounds like alkaloids, naphtha quinones, flavonoids, glycoside, steroids, Saponin, phenolic compounds, triterpenoids, coumarins, tannins, carbohydrate, fixed oils, fats, and proteins are present in different plant parts which has been reported to show antibacterial Uma Devi et al., ${ }^{3}$ anti-plasmodial, hepato protective, central nervous system stimulatory activity, anti-fungal, anti-inflammatory, antihyperglycemic, anti-atherosclerotic activity Kumar et al. ${ }^{3}$ anti-tumor, anti-cancer Roy et al. ${ }^{4}$ etc. Propagation of this plant through seed is not reliable due to its poor germination under natural conditions. Pharmaceutical companies procured the plant material from wild and which leads to the depletion of this plant rapidly. This raises the concern about extinction of this. Due to the increasing need of this plant, an alternative technology to the conventional method in improvement of crop is to utilize the biotechnological approaches. Invitro propagation is currently used to a large number of medicinally important plants for the multiplication and conservation. Earlier reports suggest that this plant can be multiplied by in-vitro propagation Rout, Wei et al., ${ }^{5-7}$ Looking at the importance of Plumbago zeylanica, in this study an effort has been done to investigate the role of different cytokinin and auxin elicitors on the growth of the plant. Different types of cytokinins and auxin provide shoot multiplication and callus induction. The present study describes the optimum condition for shoot multiplication and establishment of callus culture from nodal and leaf explants of Plumbago zeylanica.

\section{Materials and methods}

\section{Plant material}

In-vitro grown Plumbago zeylanica accession number524441 was collected from the National Bureau of Plant Genetic Resources (NBPGR). This accession was further maintained in MS
(Murashige and Skoog medium) media containing 0.2mg/l BAP in Plant Biotechnology Laboratory of Delhi Technological University.

\section{Effect of different cytokinin concentration on shoot induction}

Nodal explants were cultured in modified MS (NaNO3 instead of NH4NO3) media containing BAP (benzyl amino purine) $(1.0 \mathrm{mg} / 1$, $1.5 \mathrm{mg} / \mathrm{l}$ and $2.0 \mathrm{mg} / \mathrm{l})$ and Kinetin $(1.0 \mathrm{mg} / 1,1.5 \mathrm{mg} / 1$ and $2.0 \mathrm{mg} / \mathrm{l})$ for shoot multiplication. $\mathrm{pH}$ of the medium was adjusted to $5.8 \pm 0.2$ by using $1 \mathrm{~N} \mathrm{NaOH}$ or $1 \mathrm{~N}$ HCL before autoclaving at $121^{\circ} \mathrm{C}$ for $20 \mathrm{~min} .0 .8 \%(\mathrm{w} / \mathrm{v})$ agar was used as a gelling agent. The culture was incubated at $25 \pm 2{ }^{\circ} \mathrm{C}$ with $16 \mathrm{~h} / 8 \mathrm{~h}$ photoperiod. Visual observation was made weekly and data were recorded. After eight weeks shoot number and shoot length were recorded.

\section{Effect of different auxin concentration on callus induction}

For induction of callus, leaves from the in-vitro grown plant were excised $(0.5 \mathrm{~cm})$ and cultured on modified MS (NaNO3 instead of NH4NO3) media supplemented with 2,4-D(2,4-dichlorophenoxyacetic acid) $(1.0 \mathrm{mg} / \mathrm{l}), 2,4-\mathrm{D}(1.0 \mathrm{mg} / \mathrm{l})+\mathrm{BAP}(0.5 \mathrm{mg} / \mathrm{l}), \mathrm{NAA}$ (Naphthalene acetic acid) $(1 \mathrm{mg} / \mathrm{l})$ and NAA $(1.0 \mathrm{mg} / \mathrm{l})+\mathrm{BAP}(0.5 \mathrm{mg} / \mathrm{l})$.

\section{Statistical analysis}

Experiment was repeated thrice and each treatment had five replicates. The number of cultures per replicate varied for the experiments. Observations were recorded as the number of shoots per explants and length of shoot per nodal explant. The data were analyzed using one-way analysis of variance (ANOVA) $(p<0.05)$.

\section{Results and discussion}

\section{Effect of different cytokinin concentration on shoot induction}

In the present two different cytokinins were used i.e. BAP and Kinetin, BAP showed more effective proliferation of shoots than kinetin (Table 1), (Figure 1) express the effect of different concentration $(1 \mathrm{mg} / 1,1.5 \mathrm{mg} / 1$ and $2 \mathrm{mg} / \mathrm{l})$ of cytokinins on the shoot 
number and shoot length. Proliferation of shoots was observed in all the culture media after two weeks of incubation. There was very less proliferation observed in MS media without any growth hormone. At high concentration of both the cytokinin, shoot proliferation rate declined. Highest shoot proliferation and length was achieved in the modified $\mathrm{MS}\left(\mathrm{NaNO}_{3}\right.$ instead of $\left.\mathrm{NH}_{4} \mathrm{NO}_{3}\right)$ supplement with the $1.0 \mathrm{mg} / 1$ BAP. In the present study modified MS media was used for the first time to observe the effect on the growth of $P$. zeylanica and also the entire study was done on the $P$. zeylanica accession which was genetically identified and supplied by NBPGR.

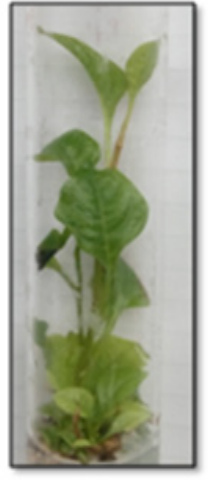

A

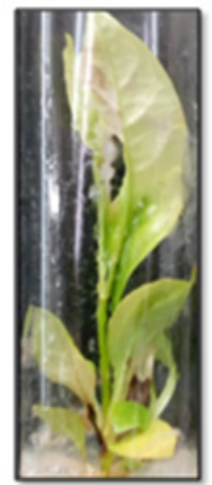

D

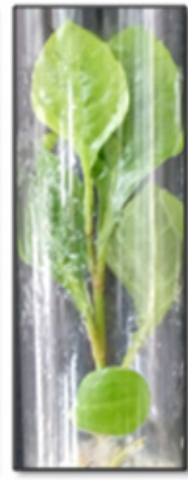

B

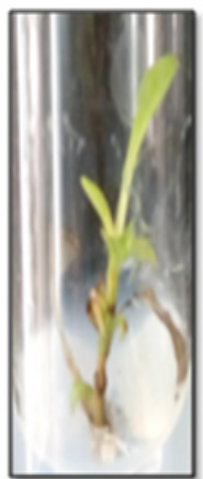

E

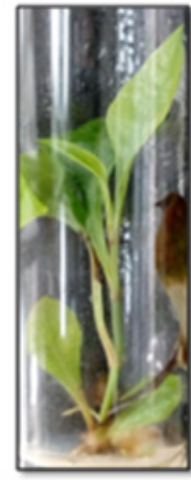

C

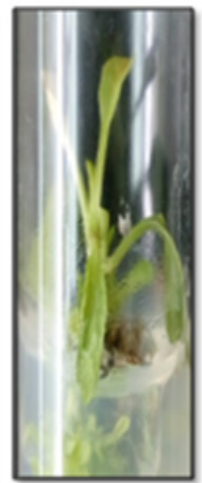

$\mathrm{F}$
Figure I Effect of different cytokinin on shoot multiplication A) MS+ I mg/l BAP, B) MS+1.5mg/l BAP, C) MS+2mg/l BAP, D) MS+I mg/l Kn, E) MS+1.5mg/l $\mathrm{Kn}, \mathrm{F}) \mathrm{MS}+2 \mathrm{mg} / \mathrm{Kn}$.

Table I Effect of cytokinins on shoot multiplication

\begin{tabular}{lll}
\hline Media & Number of shoot & Length of shoot \\
\hline MS+I mg/l BAP & $4.33 \pm 0.63$ & $5.01 \pm 0.53$ \\
MS+I.5mg/l BAP & $2.6 \pm 0.69$ & $3.48 \pm 0.44$ \\
$M S+2 \mathrm{mg} / / \mathrm{BAP}$ & $1.8 \pm 0.63$ & $1.47 \pm 0.43$ \\
$\mathrm{MS}+\mathrm{I} \mathrm{mg//} \mathrm{Kn}$ & $2.5 \pm 0.53$ & $2.62 \pm 0.46$ \\
$\mathrm{MS}+1.5 \mathrm{mg} / \mathrm{l} \mathrm{Kn}$ & $1.0 \pm 0.48$ & $1.08 \pm 0.34$ \\
$\mathrm{MS}+2 \mathrm{mg} / \mathrm{Kn}$ & $1.0 \pm 0.42$ & $0.74 \pm 0.18$ \\
\hline
\end{tabular}

Sahoo $^{8}$ studied the role on BAP and Kinetin on shoot induction of Plumbago zeylanica, where BAP supplemented MS media produced more number of shoots that the kinetin supplemented MS media. Ceasar et al. ${ }^{9}$ also reported similar kind of results in case of wild type Plumbago zeylanica plant. Gbadamosi et al., ${ }^{10}$ reported the highest shoot multiplication in MS medium containing NAA (0.01$0.05 \mathrm{mg} / \mathrm{l})$ and BAP $(2.0-4.5 \mathrm{mg} / \mathrm{l})$. Dohare et al., ${ }^{11}$ reported highest shoot formation in the combination of $1 \mathrm{mg} / \mathrm{l} \mathrm{BAP}+1 \mathrm{mg} / \mathrm{l} \mathrm{NAA}$ and maximum length of shoot was recorded $(5.38 \pm 0.99 \mathrm{~cm}){ }^{12}$

\section{Effect of different auxin concentration on callus induction}

Induction of callus was observed the cut end of leave explants after 2 weeks of incubation when modified $\mathrm{MS}\left(\mathrm{NaNO}_{3}\right.$ instead of $\left.\mathrm{NH}_{4} \mathrm{NO}_{3}\right)$ supplemented with $1.0 \mathrm{mg} / 1$ 2, 4-D and $1.0 \mathrm{mg} / 1 \mathrm{NAA}$. Whereas media supplemented with the $1.0 \mathrm{mg} / 12$, 4-D $+0.5 \mathrm{mg} / 1 \mathrm{BAP}$ and $1.0 \mathrm{mg} / \mathrm{l}$ $\mathrm{NAA}+0.5 \mathrm{mg} / \mathrm{l} \mathrm{BAP}$ did not show any callus response. An media supplemented with IBA showed root induction. Highest amount of callus induction was obtained in modified $\mathrm{MS}\left(\mathrm{NaNO}_{3}\right.$ instead of $\mathrm{NH}_{4} \mathrm{NO}_{3}$ ) supplemented with $1.0 \mathrm{mg} / 1$ 2, 4-D. Lubaina and Murugan (2012) reported that maximum callus proliferation when MS media supplemented with $1 \mathrm{mg} / 1$ 2, 4-D along with $0.5 \mathrm{mg} / 1$ BA (Table 2), (Figure 2).
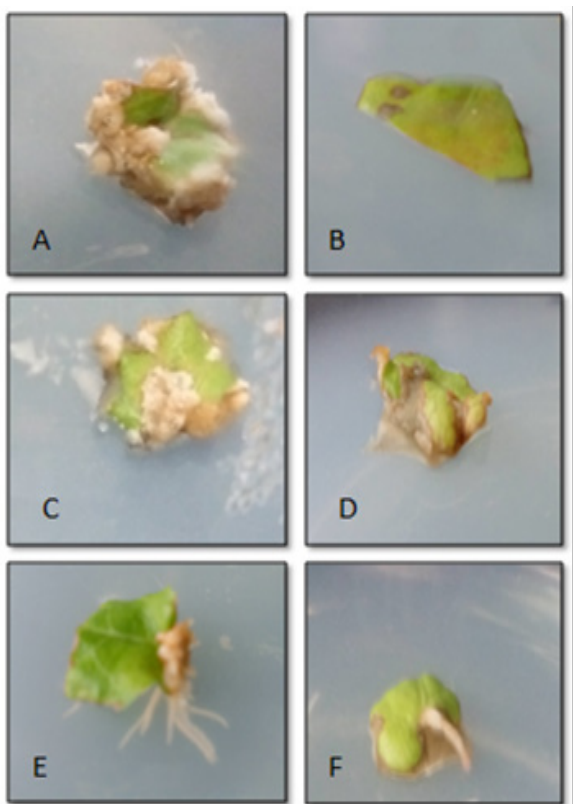

Figure 2 Effect of different auxins on callus induction $A$ ) $M S+I \mathrm{mg} / \mathrm{l} 2,4-D, B$ ) MS+ I mg/l 2, 4-D + 0.5mg/l BAP, C) MS+ I mg/l NAA, D) MS+I mg/l NAA+

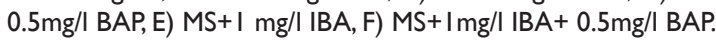

Table 2 Effect of auxins on callus induction

\begin{tabular}{ll}
\hline Media & Callus induction \\
\hline$M S+I \mathrm{mg} / / 2,4-D$ & +++ \\
$M S+I \mathrm{mg} / / 2,4-D+0.5 \mathrm{mg} / /$ BAP & - \\
$M S+I \mathrm{mg} / / \mathrm{NAA}$ & ++ \\
$\mathrm{MS}+\mathrm{Img} / \mathrm{I} \mathrm{NAA}+0.5 \mathrm{mg} / / \mathrm{BAP}$ & - \\
$\mathrm{MS}+\mathrm{Img} / \mathrm{IBA}$ & Root induction \\
$M S+I \mathrm{mg} / / \mathrm{IBA}+0.5 \mathrm{mg} / \mathrm{l} \mathrm{BAP}$ & Root induction \\
\hline
\end{tabular}

\section{Conclusion}

In this study, an attempt has been done to develop a method for the growth of Plumbago zeylanica by varying the cytokinin and auxin concentrations. Growth pattern was dependent on different growth hormones in both the shooting and rooting. $1.0 \mathrm{mg} / 1 \mathrm{BAP}$ results in the highest shoot multiplication. MS media supplemented with $1.0 \mathrm{mg} / 1$ 2, 4-D showed the faster callus induction rate. Mass propagation of 
this plant is feasible for field plantings to produce higher amount of roots which is the main source of plumbagin for the pharmaceutical industry. These in-vitro studies provide an efficient method for conservation and propagation this over exploited plant.

\section{Acknowledgements}

Our sincere thanks goes to Department of Biotechnology, Delhi Technological University for encouragement and providing necessary facilities during this investigation, Dr. Neelam Sharma, NBPGR, New Delhi for providing the plant materials.

\section{Conflict of interest}

The author declares no conflict of interest.

\section{References}

1. Chand S, Sahrawat AK, Prakash DVSSR. In vitro culture of Pimpinella anisum L (anise) J. Plant Biochem Biotech. 1997;6(2):91-95.

2. Uma Devi P, Soloman FE, et al. Plumbagin, a plant naphthoquinone with radiomodifying properties. Pharmaceutical Biology. 1999;37(3):231236.

3. Kumar R, Kumar S, Patra A, et al. Hepatoprotective activity of aerial parts of Plumbago zeylanica linn against carbon tetrachlorideinduced hepatotoxicity in rats. International Journal of Pharmacy and Pharmaceutical Sciences. 2009;1(Suppl 1):171-175.

4. Roy A, Attre T, Bharadvaja N. Anti cancer agent from medicinal plants: a review. New aspects in medicinal plants and pharmacognosy. 1st ed. Poland: JB Books; 2017.
5. Rout GR, Saxena C, Samantaray S, et al. Rapid plant regeneration from callus cultures of Plumbago zeylanica. Plant Cell Tissue and Organ Culture. 1999;56(1):47-51.

6. Wei X, Gou X, Yuan T, et al. A highly efficient in vitro plant regeneration system and Agrobacteriummediated transformation in Plumbago zeylanica. Plant Cell Rep. 2006;25(6):513-521.

7. Sivanesan I. Shoot regeneration and somaclonal variation from leaf callus cultures of Plumbago zeylanica Linn. Asian J Plant Sci. 2007;6:83-86.

8. Sahoo S. Micropropagation of Plumbago zeylanica Linn. J Herbs Spices Med Plants. 1986;5(4):87-93.

9. Ceasar SA, Ayyanar M, Ignacimuthu S. An Improved Micropropagation Protocol for Plumbago zeylanica L. An Important Medicinal Plant. Asian Journal of Biological Sciences. 2013;6:214-220.

10. Gbadamosi IT, Egunyomi A. Micropropagation of Plumbago zeylanica L. (Plumbaginaceae) in Ibadan, Southwestern, Nigeria. Journal of Medicinal Plants Research. 2010;4(4):293-297.

11. Dohare B, Jain K, Jain B, et al. Rapid clonal propagation of an endangered medicinal plant Plumbago zeylanica Linn. International Journal of Pharmacy \& Life Sciences. 2012;3(8):1883- 1887.

12. Lubaina AS, Murugan K. Effect of growth regulators in callus induction, plumbagin content and indirect organogenesis of Plumbago zeylanica International Journal of Pharmacy and Pharmaceutical Sciences. 2012;4(Suppl 1):334-336. 